\title{
Strengthening Work Ethics And Integrity In Corruption Prevention
}

\author{
Riri Tasi ${ }^{1}$, Syamsir $^{2}$ \\ \{riritasimargenta94@gmail.com ${ }^{1}$, syamsirsaili@yahoo.com $\left.{ }^{2}\right\}$ \\ Fakultas Sosial, Universitas Negeri Padang, Padang, Indonesia ${ }^{1}$ \\ Fakultas Sosial, Universitas Negeri Padang, Padang, Indonesia ${ }^{2}$
}

\begin{abstract}
Bureaucracy is the executor of government administration who has great authority in managing public assets, providing public services, and determining policies. Such power requires control to prevent abuse of authority and guidelines for creating quality government. One of the main controls that is now a problem is ethics and integrity. Without ethical and integrity standards, it will be very difficult to prevent abuse of authority, corruption, and the like. This study aims to determine the strengthening of ethics and integrity in preventing corruption. This research was conducted with a qualitative approach to find out the strengthening of ethics and integrity in preventing corruption. The location of this research is the Social Service Office of Sijunjung Regency. Samples were taken by purposive sampling technique. Data collection techniques are through observation and interviews. Data analysis technique is drawing conclusions. The results of this study are that strengthening ethics and integrity is very important and has a great influence in preventing corruption in the Social Service of Sijunjung Regency.
\end{abstract}

Keywords: Ethics, Integrity, corruption

\section{Introduction}

Bureaucracy is the executor of government administration who has great authority in managing public assets, providing public services, and determining policies. Such power requires control to prevent abuse of authority and guidelines for creating good governance. One of the main controls that is now a problem is the ethics and integrity of the bureaucracy. Without ethical and integrity standards, it will be very difficult to prevent abuse of authority, corruption, and the like.

One of the most common abuses is corruption. Corruption is literally something rotten, evil and destructive. This is due to corruption is related to moral aspects, the nature and state of decay, positions in government agencies or apparatuses, abuse of power in office due to giving, economic and political factors, and the placement of families or groups into the service under the authority of his position. Kartono (2003) explains Corruption is the behavior of individuals who use authority and position to rake in personal gain, harm the public and state interests. So corruption for personal gain, mismanagement of power, for personal gain, mismanagement of the sources of state wealth by using formal authority and powers (for example, due to legal reasons and the power of weapons) to enrich themselves [1].

Weak integrity and work ethics of the organizers or the state apparatus are the main causes of deviations and abuse of authority or power. The state apparatus is a major factor in 
the success of the government in realizing good, clean and free governance, Corruption, Collusion, Nepotism. Without apparatus with integrity and ethics, it is impossible for government work programs to run well. For this reason, one of the main aspects of the bureaucratic reform program is the reform of the aspects of human resources (HR), because this aspect will later implement or drive all bureaucratic reform programs.

However, the development of integrity and ethics of the state apparatus cannot be carried out briefly only through mere bureaucratic reform programs. The development of integrity and ethics of the state apparatus must be carried out simultaneously, from school to official education. Therefore, there needs to be a reorientation of formal education curriculum and official education by incorporating the noble values of the Indonesian nation, both originating from religion, culture and ideology of the nation. These noble values must be actualized in every state administration activity so that efforts to build the integrity and ethics of the state apparatus can be realized concretely in everyday life, so that they can finally form a state apparatus that is professional and highly disciplined.

In order to strengthen the work ethics and integrity of the government apparatus to prevent corruption, several references have been issued in the form of TAP-MPR Number VI Year 2001 [2], Law Number 28 Year 1999 [3], Government Regulation Number 42 Year 2004 [4], and various Ministerial Regulations. To improve the performance of the bureaucracy, since 2004, the government has launched the implementation of bureaucratic reform, which began with the implementation of pilot projects in 3 institutions, namely the Ministry of Finance, the Supreme Court, and the Supreme Audit Agency. To accelerate and expand the implementation of institutional bureaucratic reforms, a National Bureaucratic Reform Team was formed, led by the State Minister of PAN. With these various national policies, basically every ministry or institution and local government can carry out bureaucratic reform in their respective institutions, which basically focuses on organizational structuring, structuring business processes, and structuring human resources. In accordance with the times, the demands of society on the bureaucracy as government administrator, and civil servants are increasingly aggressive and strong to be able to hold a transparent, accountable, and quality government. This includes the integrity of reinforcement where the commitment to do everything in accordance with appropriate and ethical principles, according to values and norms, and there is consistency to continue to carry out that commitment in every situation without seeing the opportunity or coercion to obtain out of principle.

State apparatus with integrity and work ethics is one of the requirements for the realization of good, clean and $\mathrm{KKN}$-free governance. In many countries strengthening the integrity and work ethics of public officials is an effective way to build attitudes and awareness in eradicating or at least reducing corruption effectively. Furthermore, the existence of integrity and ethics can provide support for the realization of good governance. Thus, strengthening integrity and ethics is a must so that efforts to eradicate corruption can go well. The conceptual explanation above can be seen below: 


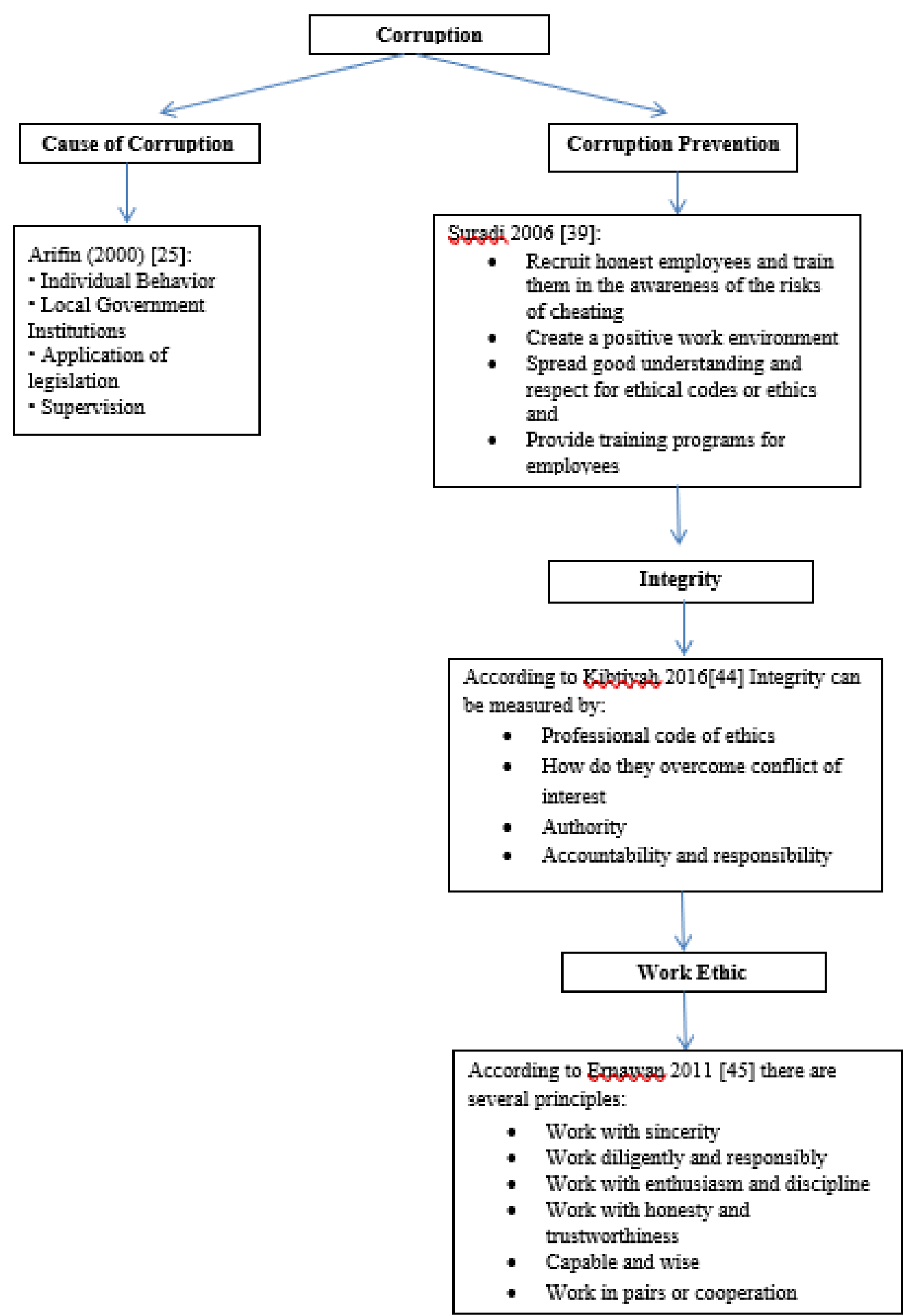

Figure 1. Conceptual Framework 


\section{Methodology}

This research was conducted with qualitative research. Qualitative research is research that is descriptive or illustrates based on facts and tends to use analysis. According to Arifin (2012) [5] Qualitative research is research to answer problems that require in-depth understanding in the context of the time and situation concerned, carried out naturally and naturally in accordance with objective conditions in the field without any manipulation, as well as the type of data collected especially data qualitative. The focus of this research is to strengthen ethics and integrity in preventing corruption. The location of this research is the Social Service of Sijunjung Regency. The population in this study were all employees of the Social Office of Sijunjung Regency, samples were taken using purposive sampling technique. Data obtained through primary data and secondary data. Data collection techniques, data presentation, and data verification or drawing conclusions.

\section{Finding and Discussion}

Corruption is closely related to the power and authority given to the authorities or government. Along with the implementation of special autonomy, the public demanded the existence of good governance practices in the management of wealth or finance of local governments as a reflection of the government's responsibility to the public for the trust given. But on the other hand special autonomy presents fears of the emergence of institutional crime in the form of criminal acts of corruption (Sudana, 2006) [6]. Corruption is bad for the welfare of society, because it encourages injustice, inefficient allocation and use of resources. Thus efforts to increase accountability are important steps that need to be taken to improve community welfare (Afrianti et al., 2014) [7].

Based on the results of interviews with employees at the Social Service of Sijunjung Regency, one of the employees said that one of the internal factors that caused corruption was the lack of strong human morals. This means that they have less moral and they are more concerned with their own interests. The results of this research are in line with the results of research found by Treisman (2000) [8] using data from 85 countries in the world to conclude several factors that cause corruption, namely a weak legal system, religious beliefs, a low level of democratization, economic development that is still in the initial stage, low salaries of civil servants, excessive State intervention, abundant natural resources, certain ethnic dominance, and high levels of decentralization. Then there are employees who say that the causes of corruption from external factors include politics, law and economics. Political factors that influence the occurrence of corruption because basically politics itself is related to power. This means that whoever that person is going to use a variety of methods, even corrupt to get that power. The legal factor can be seen from the law enforcement system which is only pro to certain parties who have an interest for themselves. Economic factors are also one of the factors that cause corruption. This can be seen from if a person's salary or income is not sufficient to meet their daily needs. Economic factors are also divided into two namely salary or income and the economic system. Not much different from the results of research by Herzfeld and Weiss (2005) [9] using 72 country data found that the factors that influence corruption are economic growth, religion, civil servants' salaries, level of democracy, political stability, economic openness, natural wealth, heterogeneity of society and law enforcement.

Then they also said that the cause of corruption was a high level of life expectancy, meaning that the salaries of employees were still low, while the needs exceeded the salary earned. corruption, namely: level of democracy, real national income, climate, literacy rate, life 
expectancy, political rights, freedom of the press, infant mortality rate, household size, population, country risk, human development index, and religion. Corruption in the local government can also be influenced by individual behavior, which is the first cause of corruption that comes from a person's mental attitude in the form of encouragement from within. Sugiarto (2012) [10]states that individual behavior which is the cause of corruption is personal favors due to abundant material ownership, accompanied by poor moral awareness, ultimately dragging the perpetrators to the belief that committing corruption is more rational than avoiding it. The more experience of corruption the more natural and rational patterns of behavior in the eyes of the culprit. The second cause of corruption comes from the Local Government Institution, which is derived from the poor Government Organization System (SOP), including regulating the bureaucratic system. A series of information in the public sector is needed in realizing good governance, both institutional reform and public management reform. Bastari, (2009) [11] explains that institutional reform involves reforming all government tools in the region, both structure and infrastructure. Another reform of public sector management concerns the financial management system of regional government. The third cause of corruption originates from the Affirmative Application of Legislation, namely the cause of corruption originating from the weakness of the existing legislation system. According to the Financial and Development Supervisory Agency. Zefri (2013) explains that the laws and regulations issued are where the regulations only prioritize the cronies of state authorities, inadequate quality of laws, inadequate judicial review, imposition of sanctions that are too light, the application of inconsistent sanctions and indiscriminate, as well as weaknesses in the field of evaluation and revision of laws and regulations. And the fourth cause of corruption is the absence of good control from internal and external parties [12]. Sopanah (2004) explains that if supervision has gone well, corruption will be reduced. Besides that public participation and transparency of public policy will enhance the oversight function carried out by the council, the process of preparing the APBD will be of higher quality [13].

Referring to various aspects that can be the cause of corruption as explained above based on the results of the interview, it can be said that the causes of corruption consist of internal factors and external factors. Internal factors are a cause of corruption that comes from personal or individual self, while external factors come from the environment or system. Corruption prevention efforts can basically be done by eliminating, or at least reducing, the two factors that cause corruption. Internal factors are determined by the strength of the anticorruption values embedded in each individual.

Anti-corruption values that must be applied and strengthened are:

a. Honesty is one trait that is very important for the life of employees, without honesty, employees will not be trusted in their social life.

b. Concern is the attitude to pay attention and to ignore (Sugono, 2008) [14].

c. Employee independence in work is required to do all the responsibilities with their own business (Supardi, 2004) [15].

d. Discipline is obedience or compliance with regulations (Sugono, 2008) [14].

e. Responsibility is the state of being obliged to bear everything (if anything happens may be prosecuted, blamed and sued) (Sugono, 2008) [14].

f. An employee's hard work will keep away from acts of corruption

Anti-corruption principles that must also be applied are:

a. Accountability is the compatibility between rules and work performance. All institutions are responsible for their performance according to the rules of the game both in the form of conventions (de facto) and the constitution (de jure), both at the 
cultural level (individual to individual) and at the institutional level (Bappenas: 2002) [16]. Public accountability has traditionally been understood as a tool used to oversee and direct administrative behavior by giving obligations to be able to provide answers (answerability) to a number of external authorities (Dubnik: 2005) [17]. Besides public accountability in the most fundamental sense refers to the ability to answer to someone related to the expected performance (Pierre: 2007) [18]. Someone given this answer must have the legitimacy to supervise and expect performance (Prasojo: 2005)[19].

b. Transparency in all policy processes is carried out openly, so that all forms of irregularities can be known by the public (Prasojo: 2007) [20]. Upholding trust because trust, openness, and honesty are the capital of students to continue their duties and responsibilities (Kurniawan: 2010) [21].

c. Fairness to prevent manipulation or unfairness in budgeting, both in the form of mark ups and others.

d. Policies and policy controls to regulate interactions so that deviations do not occur that can harm the country and society.

Thus, the Social Service of Sijunjung Regency applies the anti-corruption values, among others by strengthening the values of integrity and ethics of employees which include honesty, independence, discipline, responsibility, hard work, simple work, courage and justice. The anti-corruption values need to be applied by each individual to be able to overcome external factors so that corruption does not occur. To prevent the occurrence of external factors, in addition to having anti-corruption values, each individual needs to understand deeply the anticorruption principles of accountability, transparency, fairness, policy, and policy control within an organization or institution or society. Therefore it is necessary to strengthen the anticorruption principles and values which constitute an inseparable unity.

\subsection{The cause of corruption}

Corruption occurs due to abuse of authority and position held by officials or employees for personal interests in the name of personal or family, relatives and friends. Kristiadi (2009) states that an official is said to commit acts of corruption if he receives a gift from someone who aims to influence the decision making that prioritizes the interests of the gift giver [22]. Meanwhile, according to Dermatoto (2007) corruption is the act of public officials, both politicians and civil servants and other parties involved in acts of corruption that are not fair and not legal [23].

There are several factors that influence the occurrence of criminal acts of corruption, including individual behavior, local government institutions, firmness in the application of legislation, and lack of supervision (Pope, 2008) [24]. Arifin (2000) says that the occurrence of corruption is caused by several factors [25]:

a. Individual Behavior

Individual behavior is a function of interaction between individuals and their environment. Sugiarto (2012) states that corrupt behavior is basically a structure contained in the purpose of the ratio of actors as a result of sedimentation from repetition of corrupt practices that have been running up to now [25].

b. Local Government Institutions

The regional government institution is an institution that takes care of its own regional affairs. To form an institution, the regional government can organize an 
effective and efficient government to improve services and welfare of the community. Regions (Rasyid, 2009) [26].

c. Application of legislation

The application of laws and regulations is a determination needed so that there is efficiency in pursuing business for a purpose. Acts of corruption easily arise due to weaknesses in the application of laws and regulations which include: the existence of monolistic laws and regulations that only prioritize relatives, the quality of legislation is inadequate, regulations are less socialized, sanctions are too light, the application of inconsistent sanctions, the weak field of evaluation and revision of laws and regulations (Sopanah, 2004) [27].

d. Supervision

Supervision is a process to ensure that the objectives of the organization have been achieved. In general supervision is divided into two, namely internal supervision (functional supervision and direct supervision by the leadership) and external supervision (supervision from the legislature and the public). Supervision has become ineffective due to several factors: including overlapping supervision by various agencies, lack of professionalism in supervision, and lack of compliance with legal ethics and government by the supervisors themselves (Sopanah, 2004) [27].

More in Merican (1971) states the causes of corruption are as follows [28]:

a. A. The legacy of colonial power.

b. Poverty and inequality.

c. Low salary.

d. Popular perception.

e. Rambling Settings.

f. Insufficient knowledge from the field.

On the other hand Ainan (1982) mentions several causes of corruption, namely [29]:

a. A formulation of imperfect legislation.

b. Slow, expensive, and inflexible administration.

c. Traditions to supplement less income from government officials with tribute or bribes.

d. Where various kinds of corruption are considered normal, it is not considered contrary to morals, so people compete in corruption.

e. In India, for example bribery is rarely condemned as long as bribery is inevitable.

f. According to culture, Nigerians cannot refuse bribery and corruption, unless they assume they have overestimated their wealth and wealth.

g. When people don't respect official rules and the goals of government organizations, why do people have to question corruption.

From the opinions of the experts above, it can be concluded that the causes of corruption are as follows: 1. Low salaries, imperfect legislation, slow administration and so on. 2. Legacy of colonial rule. 3. mental attitude of employees who want to get rich quickly in a way that is not lawful, there is no state awareness, no knowledge in the field of work carried out by government officials.

Furthermore, there are some consequences raised by Mc Mullan (1961) that because corruption is inefficient, injustice, people do not trust the government, wasting state resources, do not encourage companies to try especially foreign companies, political instability, restrictions on 
government policies and don't be repressive [30]. Based on the opinions of the experts above, it can be concluded that the consequences of corruption above are as follows:

a. Economic arrangements such as capital flight abroad, disruptions to companies, disruptions to investment.

b. Socio-cultural governance such as social revolution, social inequality.

c. Political arrangements such as takeover of power, loss of foreign aid, loss of government authority, political instability.

d. Administrative procedures such as inefficient, lack of administrative capacity, loss of expertise, loss of state resources, limited government policy, taking repressive measures. In general, the consequences of corruption harm the state and damage togetherness and slow down the achievement of national goals as stated in the Preamble of the 1945 Constitution.

Corruption cannot be left unchecked if a country wants to achieve its goals, because if left unceasing, it will be used and become fertile and will lead to the mental attitude of officials who are always looking for easy shortcuts and justify all means (finally justifying ways) . For this reason, corruption needs to be handled thoroughly and responsibly.

\subsection{Types of corruption}

Kartono (1983) sets limits on corruption as individual behavior that uses authority and position to gain personal gain, harming the public and State interests [9]. So corruption is a symptom of abuse and mismanagement of power, for personal gain, mismanagement of the source of state wealth by using formal authority and power (for example due to legal reasons and the power of weapons) to enrich themselves. Corruption occurs because of abuse of authority and positions held by officials or employees for personal interests on behalf of personal or family, relatives and friends [31].

Wertheim (in Lubis, 1970) states that an official is said to commit acts of corruption if he receives a gift from someone who aims to influence him so that he makes decisions that favor the gift giver. Sometimes people who offer gifts in the form of gifts are also included in corruption [32]. Furthermore, Wertheim added that remuneration from a third party received or requested by an official to be passed on to his family or party / group or people who have a personal relationship with him, can also be considered as corruption. In such circumstances, it is clear that the most prominent feature in corruption is the behavior of officials who violate the principle of separation between personal interests and the interests of society, personal finance with the public.

According to Beveniste in Suyatno (2005) corruption is defined in 4 types, as follows

a. Discretionary corruption is corruption committed because of the freedom to determine a policy, even if the policy appears to be legal, not an acceptable practice for members of the organization. Example: A waiter from a Foreign Worker's license, provides faster services to "brokers", or people who are willing to pay more, than ordinary applicants. The reason is because the broker is a person who can provide additional income.

b. Illegal of Corruption, is a type of action intended to interfere with the language or purpose of law, rules and regulations. Example: The auction rules state that for procurement of certain types of goods, it must go through an auction or tender process. But because time is very urgent (due to late budget reductions), the process is not possible. For project leaders looking for a legal basis that can support 
or strengthen implementation so that it is not blamed by the inspector. The articles in the regulation are discussed which can be used as a legal basis to strengthen the validity of tenders. In implementing a project like this case, it is actually valid or invalid, depending on how the parties interpret the applicable regulations. Even in some cases, the location of illegal corruption lies in the sophistication of play on words; not substance.

c. Mercenery from corruption, is a type of corruption aimed at personal gain, through the abuse of authority and 22 forces. Example: In a tender competition, the auction committee has the authority to pass bidders. For this reason, he said in secret or said that in order to win the tender, participants had to be willing to give some "bribe" or "polish" money.

d. Corruption ideology, is a type of illegal corruption or wisdom intended to pursue group goals. Example: The floodgate scandal case is an example of ideological corruption, in which a number of individuals gave their commitment to President Nixon rather than the law or the law. Sale of BUMN assets to support winning the general election

Aditjondro (2003) applicatively there are three layers of corruption, namely [34]:

a. First Layer Corruption Bribery

that is, where the initiative comes from employers or citizens who need services from bureaucrats or public service officers, or cancellation of the obligation to pay fines to the state treasury, extortion where the initiative to ask for compensation comes from bureaucrats or other public service officers.

b. Second Layer Corruption

Corruption networks between bureaucrats, politicians, law enforcement officers and companies that have a special position. Usually there is a nepotistic bond between several members of the corruption network that can be of national scope.

c. Third Tier Corruption

Corruption networks are international in nature, where the position of law enforcement officers in the second tier corruption model is replaced by debtor institutions and / or international institutions that have authority in the business of foreign airlines whose products are selected by the regime leader who is a member of the international corruption network.

\subsection{Efforts to tackle corruption}

There are several attempts to overcome corruption offered by experts, each of which is seen from various aspects and views. Caiden (in Soerjono, 1980) provides the following steps to tackle corruption [35]:

a. Justify a transaction that was previously prohibited by specifying a certain payment amount.

b. Create a new structure that underlies how decisions are made.

c. Making organizational changes that will facilitate the problem of oversight and prevention of centralized power, rotation of assignments, overlapping authority of the same organization, competing bureaucracy, and the appointment of a supervisory body are clear suggestions found to reduce opportunities for corruption. 
d. How to reduce corruption? by increasing threats.

e. Corruption is a matter of value.

Furthermore, Myrdal (in Lubis, 1987) recommends corruption prevention measures so that the arrangements and procedures for administrative decisions regarding individuals and companies are simplified and strengthened, enforcement of tighter controls, personal policies in exercising power must be reduced as far as possible, low employee salaries must be increased and improved socioeconomic position, safer, security units including the police must be strengthened, criminal law and corrupt official law can be more quickly taken. Those who bribe officials must be dealt with as well [36]. The issue of corruption varies in the way it is seen, and therefore the research methods also vary. Corruption is not enough in terms of deductive course, but needs to be advanced in terms of inductive which starts to see practical problems (practical problems), also must be seen what causes corruption. Kartono (1983) suggested handling corruption as follows [37]:

a. People's awareness to be responsible for political participation and social control, with ignorance.

b. Instill positive national aspirations, which give priority to national interests.

c. Leaders and officials set an example, eradicate and crackdown on corruption.

d. Sanctions and the power to act against, root out and punish acts of corruption.

e. Reorganization and rationalization of government organizations, by simplifying the number of departments, along with the offices below.

f. There is a recruitment system based on "achievement" and not based on a "supposition" system

g. There is a need for non-political civil servants for the smooth administration of government.

h. Creating an honest government apparatus

i. The budget system is managed by officials who have high ethical responsibilities, accompanied by efficient control system.

j. Re-registration of striking individual wealth with high taxes.

Marmosudjono (Kompas, 1989) said that in eradicating corruption, the shame of corruptors by showing the face of corruptors on television because according to him, going to prison was no longer considered shameful [38].

Suradi 2006 [39] there are four factors which factors can be used in preventing acts of corruption, namely:

a. recruiting honest employees and training them in the awareness of the risks of cheating;

b. creating a positive work environment;

c. spread good understanding and respect for codes of ethics or ethics; and

d. provide training programs for employees.

\subsection{The factors to forming integrity}

According to Syamsir, et al (2019) Integrity was harmony between what was said and what was done by someone. His actions were in accordance with moral demands and ethical principles and in accordance with the rules of law and do not wrong the public interest. Integrity referred to the quality of trustworthiness in a human being in which there are individual qualities such as honest character, trustworthiness, responsibility, maturity, courtesy, willingness to be kind and so on. Integrity comes from the word integrity, which means soundness of moral 
principle and honesty character [40]. In other words, those who have integrity, usually have a clear conscience, have strong moral principles, are fair and honest and are not afraid of anyone except God (Eko B. Supriyanto in Kibtiyah 2016) [41]

Zahra (2011) integrity is a commitment to do everything according to principles that are right and ethical, in accordance with values and norms, and there is consistency to continue to make this commitment in every situation without seeing the opportunity or coercion to get out of principle [42] . Whereas Mulyadi, (2010) further stated that integrity is a quality that underlies public trust and is a benchmark for employees in testing all decisions they make [43]. Employees with integrity are employees who have the ability to realize what they believe to be reality.

Eileen Rachman in Kibtiyah 2016) [44] said a person's integrity can be measured by several indicators, namely:

a. Professional code of ethics. How high is this code of ethics upheld, especially by company leaders who will be emulated by subordinates.

b. How do they overcome conflict of interest. In this case the extent to which provisions have been determined and agreed upon can be adhered to.

c. Authority. How well the authority given can be utilized.

d. Accountability and responsibility. If you experience problems, what will be done whether running or facing it.

\subsection{Ethical Principles at work}

According to Ernawan 2011 [45] there are several ethical principles at work, including

a. Work with sincerity.

Working with sincerity means working willingly. Every employee must realize the work carried out is of their own volition, not coercion.

b. Work diligently and responsibly

Perseverance is seriousness in doing the work of the organization developing things that can be emulated or emulated in doing work in the organization. Whereas responsibility is to carry out the task seriously, act based on professionalism, and be obedient and loyal in carrying out the task.

c. Work with enthusiasm and discipline.

Being enthusiastic means having high encouragement to constantly improve performance and being willing to take advice or reprimand. Discipline means being disciplined in action, obedient and obedient to the rules of the law with discipline will guarantee work productivity.

d. Work with honesty and trustworthiness.

Trustworthiness and honesty that means fulfilling the promise and constantly fulfilling the standard of honesty, sincerity for all our actions and statements.

e. Capable and wise.

Being capable means increasing skills for oneself and for others, trying to broaden knowledge and acting cautiously by continuing to learn and explore knowledge. Being active in the sense of being open and responsive to change, being able to accept and give constructive criticism, making informed judgments Be careful before deciding on an action, be patient in dealing with problems and calm in experiencing pressure.

f. Work in pairs / cooperation 
Cooperation is the management of carrying out or carrying out an activity or business that is handled by two or more people in working to achieve organizational goals.

\section{Conclusion}

Corruption that often occurs today, is in a very severe position and is so rooted in every aspect of life. The development of corruption practices has increased from year to year, both in terms of the amount or amount of state financial losses and in terms of quality that is increasingly systematic, sophisticated and has a broad scope in all aspects of society. Based on the results of research it can be concluded that efforts to prevent corruption in the Office The Social Service of Sijunjung Regency is by strengthening the values of integrity and work ethics in carrying out their duties. Integrity and ethics require employees to be honest, caring, disciplined, responsible, and work hard. By strengthening the values of integrity and ethics of employees, it will create good governance and free from corruption.

\section{References}

[1] K. Kartono, “Leaders and Leadership”. Jakarta: PT Raja Grafindo Persada, 2003.

[2] MPR Decree Number VI / MPR / 2001 of 2001, Regarding the Ethics of National Life .

[3] Law No. 28 of 1999 concerning State Administration that is Clean and Free of KKN

[4] Regulation of the Government Number 42 Year 2004 About Coaching Mental Corps and the Code of Conduct Employees of State Civil

[5] Arifin, Zainal . 2012. Penenlitian Education Methods and Paradigm New . Bandung: Youth Rosda Karya

[6] I. M. Sudana, Management To uangan Company, 2nd ed. Jakarta: Erlangga, 2006.

[7] A frianti, et al. Anti-Corruption Values and Principles 2014

[8] Treisman , Daniel . 76, 3, June 2000, pp.399-457, The Causes of Corruption: A CrossNational Study, Published in the Journal of Public Economics,

[9] Herzfeld, Thomas Weiss . 2005. "Corruption Legal in Effectiveness: An Empirical Investigation ".

[10] Sugiarto . 2012. Pembrantasan Corruption : Overview of Duality Structure and Actors .

[11] Aprilia , Surita . 2019 .P ersepsi On Factors That Affect Corruption ( Study On SKPD In Banda Aceh) . Journal of Scientific Mahas ISWA Economic Accounting (JIMEKA ) Vol . 4, No. 2, (2019) Page 279-285

[12] Aprilia , Surita . 2019 .P ersepsi On Factors That Affect Corruption ( Study On SKPD In Banda Aceh) . Journal of Scientific Mahas ISWA Economic Accounting (JIMEKA ) Vol . 4, No. 2, (2019) Page 279-285

[13] Polite . 2004. Pubic Budget Analysis : TOT Guide, Malang Corruption Watch (MCW). Jakarta.

[14] Sugono Dendy . 2008. Kamus Besar Languages Indonesia. Jakarta: Language Center of the Ministry of National Education

[15] Aprilia , Surita . 2019 .P ersepsi On Factors That Affect Corruption ( Study On SKPD In Banda Aceh) . Journal of Scientific Mahas ISWA Economic Accounting (JIMEKA ) Vol . 4, No. 2, (2019) Page 279-285

[16] Bappenas . 2002 Report of Development Economics Macro : January - October 2002. 
[17] Aprilia , Surita . 2019 .P ersepsi On Factors That Affect Corruption ( Study On SKPD In Banda Aceh). Journal of Scientific Mahas ISWA Economic Accounting (JIMEKA ) Vol . 4, No. 2, (2019) Page 279-285

[18] Pierre , Jon and B. Guy Peters , 2007 . Governance, Politics and The State, London : Macmillan Press LTD

[19] Prasojo Eko . 2005. Democracy in the Land of Dreams : Critical Notes on the 2004 Elections and Good Governance. Depok : Department of Administrative Sciences FISIP UI.

[20] Prasojo Eko . Teguh Kurniawan . Defny Holidin . 2007. Bureaucracy Reform and Innovation : Study in Sragen Regency . Jakarta: Department of Administrative Sciences FISIP UI and Yappika -CIDA.

[21] Kurniawan , Muhammad. 2013. Oversight of the spirit of commitment to the Organization , Cultural Organization , and Satisfaction Job Ter face- Performance Organization Public ( Study On Government District Kerinci ). Thesis . Universitas Negeri Padang.

[22] Kristiadi.2009. Corruption Corrupts Indonesia. Jakarta: Gramedia Main Library .

[23] Argyo , Dermatoto . 2007. Corruption Behavior in the Era of Regional Autonomy, Empirical Facts and Corruption Eradication Strategies in Indonesia. Public Spirit Journal, Vol 3, No 2, (89-102).

[24] Black, B and Pope, T. (2008). Developmental psy chology: incorporating Piaget's and Vygotsky's theories in classrooms . Journal of Cross-Disciplinary Perspectives in Education, 1 (1), p . 59-67

[25] Atmadja , Arifin P. Soeria . 2000. Public Finance in the Legal Perspective Theory , Practice and Criticism , Jakarta: FH UI .

[26] Rasyid , Muhammad Ryaas . 2009 . Meaning Pemeri ntahan - Overview of the terms of the Ethics and Leadership . Jakarta: PT. Mutiara Sumber Widya .

[27] Polite . 2004. Pubic Budget Analysis : TOT Guide, Malang Corruption Watch (MCW). Jakarta.

[28] Merican. 1971. Introduction to Legal Studies , Alumni, Bandung .

[29] Nugroho . 2012. Corruption And Factors That Affecting d i Indonesia .Jurnal Media Economics and Management

[30] Wiranta , 2016. Bureaucracy Transformation : Ways to Strengthen Ethics and Integrity in Corruption Prevention. Widyaiswara Circle Journal

[31] Kartono , Kartini . 1983. Social Pathology . CV Rajawali . Jakarta

[32] Lubis , Mochtar . 1977 Flower Potpourri Ethics Employees State . Jakarta. Bhratara . Script work .

[33] Suyatno . 2005. Corruption , collusion , and nepotism . Jakarta: Sinar Harapan Library .

[34] Aditjondro , George Junus. 2003. Journal of Discourse : No Matter of Eggs and Chickens :Build a framework that is more holistic for the movement of anti-corruption in Indo Eng. Yogyakarta: Insist Press.

[35] Dirdjosisworo , Soedjono , 1980, " Issues Development Act Criminal Corruption in Indonesia". In the Justice Library, Supreme Court, Jakarta.

[36] Lubis , Mochtar . 1977 Flower Potpourri Ethics Employees State . Jakarta. Bhratara . Script work .

[37] Kartono , Kartini . 1983. Social Pathology . CV Rajawali . Jakarta

[38] Marmosudjono . 1989 . Law Enforcement in the State of Pancasila , Pustaka Kartini , Jakarta

[39] Suradi , Corruption in the Government and Private Sector , Yogyakarta: Gava Media, 2006 
[40] Syamsir , et al, "The Model of Integrity Development Among Public Servants in Government Institutions of Padang City" Research Report: LP2M. 2019

[41] Kibtiyah , A., \& Mardiah . (2016). Relationship of Integrity and Employee Loyalty with Vision Mission Company ( Study Case At PT. Bank Central Asia, Tbk ).

[42]Zahra. (2011). Effect of integrity , competence and loyalty Kepemimp inan Against Belief The Liege in SBU Shipping PT. Pusri Palembang. Scientific Journal of Business Oration, VI , 2085-1375.

[43] Mulyadi . 2010. integrity, 3rd Edition, 5th Printing . Salemba Empat Publisher, Jakarta.

[44] Kibtiyah , A., \& Mardiah . (2016). Relationship of Integrity and Employee Loyalty with Vision Mission Company ( Study Case At PT. Bank Central Asia, Tbk ).

[45] Ernawan , Erni R. (2011). Organizational Culture in Economic and Business Perspectives . Bandung : Alfabeta 